\title{
The Adoption of Service Learning in Universities Around The World
}

\author{
Stuart Umpleby, Gabriela Rakicevik
}

\begin{abstract}
In the United States, service learning has proven to be an effective means for both education and for community development. It seems logical to assume that service learning would be similarly effective in other countries. However, universities in other countries operate quite differently from universities in the U.S. Discussions with professors from the former Soviet Union and Southeast Europe produced a list of obstacles to transferring service learning to other countries. This paper suggests some ways of minimizing these obstacles. As service learning is implemented in universities around the world, opportunities for people to learn from the experiences of others will increase.
\end{abstract}

Key words: Service Learning, University, Countries

JEL : 121,129

DOI: $10.2478 / v 10033-007-0007-z$

\section{A History of Service Learning in the United States}

Students and faculty members at U.S. universities have been doing volunteer work with local non-governmental organizations (NGOs) for many years. Also, the agricultural and industrial extension services of mid-western universi-

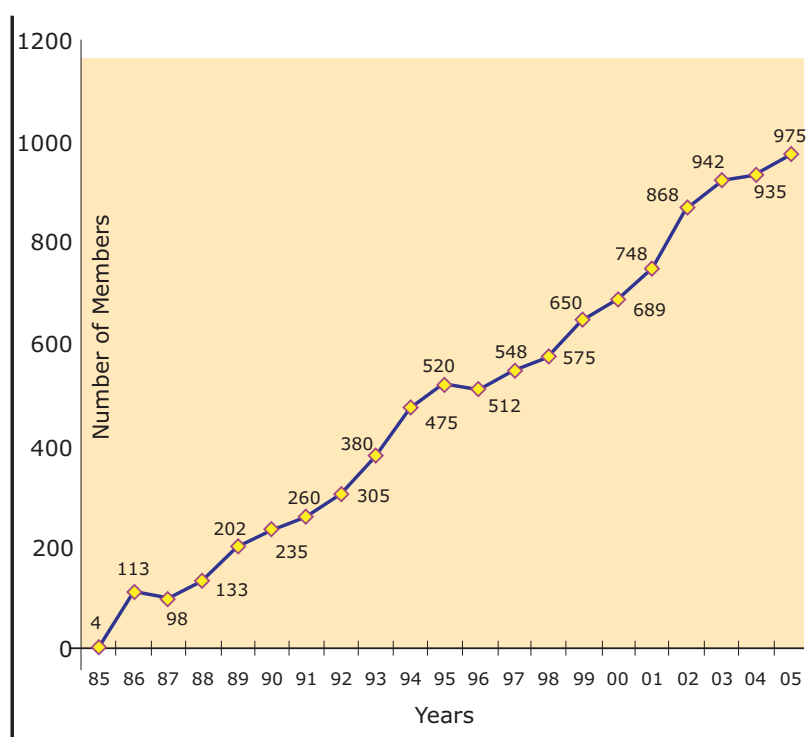

Figure 1.

Growth of Campus Compact Since 1985 ties date back to at least the Morrill Act in the 1860s. However, service learning $(S L)$ as a method of instruction is a rather recent invention.

One indication of the spread of service learning is the growth in membership of Campus Compact. Campus Compact was founded in the mid 1980s by the presidents of three universities - Brown University, Georgetown University and Stanford University. Their intent was to encourage the presidents of other universities to encourage faculty, students and staff to engage in service activities. The "compact" is a statement that university presidents are asked to sign. If

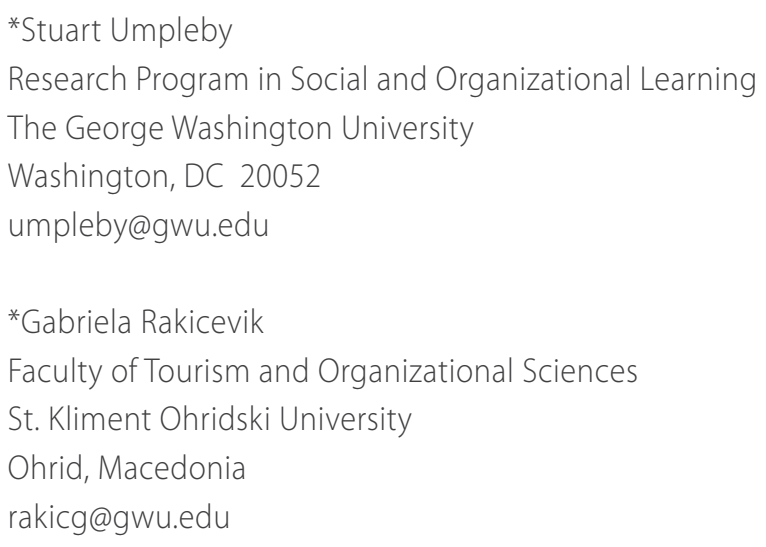


the president signs, that university becomes a member of Campus Compact (www.compact.org) and becomes publicly committed to engaging in service learning activities.

\section{Literature Review of Service Learn- ing}

Service Learning has been studied from several points of view, depending on the interests of researchers. Key topics that have been discussed include implementation of SL in curricula, methods of implementation, establishment of collaboration with the community, and benefits of SL for all parties (students, faculty, community and educational institution).

The motivation of faculty members to adopt SL as a method of instruction was studied by Barbara Holland (2000). She found that there are different sources of faculty motivation. Faculty members might be motivated by personal values, values that inspire their commitment to a life of service, the success of their discipline and the quality of their teaching and research. Hence, SL and collaboration with the community can be a result of either individual or professional goals.

Measuring the outcomes of SL for the various parties has been attempted by many authors (Markus, et al., 1993; Bringle and Kremer, 1994; Giles and Eyler, 1994, Cohen and Kinsey, 1994; Hesser, 1995). In their studies, they pay most attention to the outcomes for students. The most difficult to measure or identify are the outcomes for educational institutions. The benefits for the community are obvious. Students do work that otherwise would increase the expenses of community organizations. Clearly, both students and client organizations benefit. Some participants benefit more than others, but certainly the implementation of SL as part of a course will have positive impacts on students, faculty, community and educational institutions. We assume the interactive learning model will be increasingly accepted, since it is student-oriented.

Incorporating SL in curricula enables students to gain practical experience related to their field. Students learn to cope with real problems, write case studies, establish relationships with professionals within the field, and perhaps become more creative. Experience is the most important factor in accomplishing these goals. SL in the curriculum can be implemented in several ways (Enos, Troppe, 1996).
In terms of receiving credit, SL can be a fourth-credit option (add a fourth credit to a regular three-credit course) or a stand-alone module (three credits). Also, a service learning assignment can be part of a normal course. In terms of its place in the curriculum, SL can be incorporated into an introductory course, a required course, or an elective course. $\mathrm{SL}$ can be included as course clusters, as capstone projects, etc. Each university needs to adjust the implementation of SL depending on the field and the abilities of students. $S L$ can be implemented in every field, but not in every course.

Establishing partnerships between a university and its community is very important. Partnerships are usually established in three stages: designing partnerships based on values, building collaborative working relationships among partners, and sustaining the partnerships (Torres, Schaffer, 2000). In many SL activities students work as individuals on tasks arranged by NGO leaders and university administrators. However, in graduate management classes students often do projects as groups with organizations where one student is employed.

\section{Stages in the Development of Ser- vice Learning in the U.S.}

The growth of service learning as a teaching method in the U.S. can be described as passing through several stages.

1. Students have long worked in groups to complete alarge assignment. This is a step beyond lectures, exams, and term papers.

2. At least by the 1970s students began doing group projects with clients in organizations. By the end of the 1970s many projects were not just hypothetical projects or laboratory exercises. Rather, they became projects with real clients with real problems.

3. By the 1980s the term "service learning" was invented and defined as a pedagogical method.

4. Books and articles on service learning began to appear in the literature on education.

5. Articles on service learning began to appear in discipline-focused journals. 


\section{Extending Service Learning to Other Countries}

As service learning has become more widely practiced in the U.S., work with students and clients overseas has occurred. The extension of SL beyond the local area has been made possible by the internet. Student projects at The George Washington University provide some examples. In the mid-1990s graduate students in business in Washington and in Moscow communicated via email in an effort to identify some possibilities for joint ventures. These contacts were possible because the Russian professor, Pavel Makeyenko, had been a visiting scholar in Washington and knew Stuart Umpleby at GWU. A second project between the students of Makeyenko and Umpleby attempted to find a U.S. firm that made management training videos and that would be willing to have them translated and marketed in Russia. (Makeyenko and Umpleby, 2005) Figure 2 depicts the evolution of SL projects in the U.S.

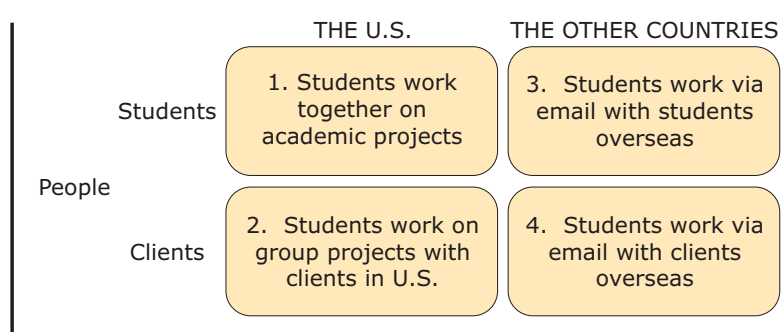

Figure 2.

The Evolution of SL Projects in the Field of Management

\section{Some Obstacles to Implementing Service Learning in Other Countries}

Since SL has been successful in the U.S. both as a pedagogical method and in helping the organizations of civil society, it seems reasonable to ask whether $\mathrm{SL}$, if implemented at universities in other countries, would be effective in other countries as well. In Spring 2006 a group of visiting professors from the former Soviet Union and the former Yugoslavia were asked this question. They described several obstacles to implementing service learning in their countries. Here are their answers.

\section{Low Faculty Salaries}

Faculty salaries in many countries are quite low. Often faculty members need to teach at more than one university to earn money, or they take second or third jobs outside of academia in order to provide for their families. Universities in other countries usually do not have financial resources to encourage faculty members to be innovative in the way they teach. Faculty members often do consulting to make extra money. In countries where academic incomes are low, any activity that looks like consulting is only of interest if it earns income. Usually faculty members do not want to share this work and income with students. Professors may see students as competitors for consulting assignments. If so, professors may argue that students do not yet know the theory and that they need to study for exams. Professors may say students should focus on learning theory first.

\section{Students Need Money}

Frequently, internships are part of the educational experience in other countries. However, internships are intended to provide business experience, not learning through service with NGOs. Senior students sometimes have an obligatory internship for which they are required to write a report. Internships provide a connection to practice but usually are arranged with financially successful businesses rather than with financially struggling NGOs. However, students may well support service learning with NGOs as an effective learning method.

\section{Service Learning is Not Known or Understood in Many Countries}

In former communist countries, "voluntary activity" usually meant a "work day" or "subotnik," for example, harvesting potatoes or cotton or shoveling snow off roads. Hence, people are likely to have a negative view of service learning. They may see it as compulsory, uncompensated work. Another problem is that in some countries the selection of clients for service learning projects may be influenced by political considerations. For example, faculty members and students might be told to work with one political faction and not another. Consequently, historical experience will cause some people to interpret SL as a form of unpaid labor to aid the politically powerful.

Faculty motivation could be a big obstacle to implementing service learning in curricula. Faculty might have a lack of confidence in their skills and knowledge about SL. If they had no experience with SL as students, they will be cautious about introducing SL in their courses. Accordingly, training of faculty may be required.

Service learning as a concept and practice is not yet understood by faculty and administrators in other countries. It needs to be explained and demonstrated. 
Faculty and students may feel that projects would be additional work, both for students and faculty, rather than a different teaching method. Local organizations with which students would work are also unfamiliar with service learning. The concept and practice will have to be explained. Currently there is very little connection between universities and local organizations in most countries.

In the U.S., the functions of a university are usually defined as education, research, and service. In the Soviet Union universities engaged in education. Institutes performed research. In many countries "service" is not widely recognized as one of the functions of a university. Widespread acceptance of service as a function of universities will take time. Ideally, the concept of SL would be supported by all professors in a department or school. This does not mean that $S L$ should be incorporated into all courses. However, it is important to encourage the faculty members who would like to implement SL.

\section{The Curriculum Limits What Can Be Done}

In many countries the curriculum is designed by the Ministry of Education, not faculty members at universities. If the curriculum does not include service learning, a faculty member can add it only as an additional requirement. Sometimes there are obstacles not in how courses are taught, but in the curriculum for a degree. Sometimes the curriculum consists of only required courses. Hence, there is no room in the curriculum for innovative courses that involve service learning. Faculty members often do not have freedom to design curricula. And students sometimes do not have elective courses they can take.

Companies choose the best students for internships. This practice prods students to study and obtain good grades. Students strive to have internships with businesses in order to earn money and to find jobs after graduation, not to do service with NGOs. Therefore, the ways that students are motivated to study may be in conflict with service learning.

\section{The Way Courses Are Taught Limits Teaching Methods}

In some countries, students do not decide until the end of the course whether they want to take the test in the course. Often students only listen to lectures and do not seek credit for the course by taking the test. This means that students are not committed to doing the work in the course until the end of the semester. This arrangement means students cannot be required to do projects during the semester.

\section{Strategies for Removing the Ob- stacles}

Perhaps in coming years universities around the world will adopt as part of their mission working with organizations in the local community. This may be done in part to achieve a higher level of performance from students, but also because a university is a key resource for social change and improvement. The functions of a university would then be defined as education, research, and service.

To increase the amount of service learning done in a university it is necessary to provide support in the form of help with logistics, planning, evaluation and communication. Also, more universities can be encouraged to adopt SL as a teaching method by creating an organization like Campus Compact in each country.

Establishing strong, stable relations with the local community and partnerships with institutions is crucial. Without collaboration with the local community it is impossible to implement any kind of SL.

Creating incentives and rewards for faculty members is very important for successful motivation, particularly in countries where faculty members must work more than one job to support their families. Creating a positive image of faculty engaged in SL is important.

To remove obstacles in the curriculum, special courses that include a service learning component could be created. In these courses students would commit to the course at the beginning of the semester. Perhaps someday SL will be added to the Bologna Process.

\section{Service Learning at Different Stages of Country Development}

Zhelyu Vladimirov (2006) has suggested that "service learning" will be interpreted differently depending on the stage of development of a country. He lists the key concerns at different stages of country development.

1. Basic survival. Faculty members will work on SL only if they are paid to do so.

2. Internships for students. Students need income as well as faculty. Faculty may supervise internships to help students. 
3. Consulting jobs for faculty. Faculty motivation is provided by the possibility of supplementary income in the future for work as a consultant.

4. Alumni groups may start service projects. In more prosperous societies alumni may contribute money to universities for scholarships for students.

\section{Cultural Differences and Service}

\section{Learning}

When this paper was presented at a conference on Community Research and Learning at American University in Washington, DC, on April 29, 2006, a question was raised about cultural differences. It was suggested that perhaps community service is done differently in different countries. For example, the concept of service learning may be the way that people in individualist countries help others. In collectivist societies people may help others through ties of family, community, religion, or tribe. This is an important question. The answer for the moment is that when service learning is described to people from collectivist societies, and they are asked whether such activities exist in their countries, they have replied that service learning is not used as a pedagogical method for the reasons described above. Service learning can be adopted either as a way of helping the local community or as an effective teaching method, or both. $[$. 


\section{References}

Albert, G., et al. (1994). Service - Learning Reader, Reflections and Perspectives on Service, National Society for Experiential Education, North Carolina.

Campus Compact (2000). Introduction to Service-Learning (Toolkit), Readings and Resources for Faculty.

Campus Compact (2003). Introduction to Service-Learning Toolkit, Readings and Resources for Faculty, Second edition.

Enos, S.L. (1996). "Service -Learning in the Curriculum," Service Learning in Higher Education: Concepts and Practices, Barbara Jacoby and Associates (eds.), San Francisco: Jossey-Bass.

Michigan Journal of Community Service Learning, Vol.1, Nr.1., A Publication of the Office of Community Service Learning at the University of Michigan, Fall 1994.

Torres, J., Schaffer, J. (2000). "Benchmarks for Campus/ Community Partnerships," Providence: Campus Compact.

Umpleby, Stuart A. (2005). "How Graduate Students in Management do Projects with Local and International Organizations," CoRAL Conference, The George Washington University, April, 30, 2005.

Umpleby, Stuart A. and Pavel A. Makeyenko (2005). "Using Email in International Student Group Projects," Proceedings of the Annual Conference of the Society for Applied Learning Technology, Arlington, VA, August 24-26, 2005.

Vladimirov, Zhelyu. Private correspondence while Vladimirov was at The George Washington University in Fall 2006 . 